\title{
The Response of $\mathrm{Mg}^{2+}$-limited Anacystis nidulans to Alterations in Photon Fluence Rate When Grown in Chemostats: a Suitable System for Studies of $\mathrm{Mg}^{2+}$-controlled Cell Division
}

\author{
By HANS CHRISTIAN UTKILEN*† AND TORMOD BRISEID \\ Botanical Institute, University of Oslo, PO Box 1045, Blindern, Oslo 3, Norway
}

(Received 4 January 1984; revised 29 May 1984)

The effect of photon fluence rate on Anacystis nidulans grown in $\mathrm{Mg}^{2+}$ - and non- $\mathrm{Mg}^{2+-}$ limited continuous cultures was studied. A decline in photon fluence rate from 445 to $30 \mu \mathrm{E} \mathrm{m}^{-2} \mathrm{~s}^{-1}$ resulted in a decrease of the mean cell volume from 2 to $0.8 \mu \mathrm{m}^{3}$ in the $\mathrm{Mg}^{2+}$-limited culture. Compared with non- $\mathrm{Mg}^{2+}-$ limited cultures, this was the only obvious difference found when decreasing the photon fluence rate. Altering the photon fluence rate for a $\mathbf{M g}^{2+}$-limited chemostat therefore seems to be a suitable system for studies of the $\mathrm{Mg}^{2+}$-controlled events in cell division of $\boldsymbol{A}$. nidulans. At constant dilution rate, the DNA content per unit cell volume was independent of photon fluence rate, while the RNA content decreased with this factor. The $\mathrm{RNA} /$ protein ratio decreased by a factor of 3 in both $\mathrm{Mg}^{2+}$ - and non- $\mathrm{Mg}^{2+}$-limited cultures, when decreasing the photon fluence rate from 445 to $100 \mu \mathrm{E} \mathrm{m}^{-2} \mathrm{~s}^{-1}$. The RNA efficiency therefore varied with photon fluence rate and the organism seemed to have surplus RNA at high light intensities.

\section{INTRODUCTION}

Cell division is the ultimate result of a complicated series of co-ordinate events involving DNA (Clark, 1968) and protein (Pierucci \& Helmstetter, 1969) synthesis and several genes (Lutkenhaus \& Donachie, 1979). Many factors can therefore directly or indirectly interfere with cell division. Magnesium seems to be an important element in this respect, since it controls cell division in prokaryotes (Webb, 1949; 1953) as well as in eukaryotes (Finkel \& Applemann, 1953; Alhuwalia et al., 1978), but little is known about the mechanism of control.

Utkilen (1982) demonstrated that in Anacystis nidulans, cell division is uncoupled from biomass synthesis during $\mathrm{Mg}^{2+}$-limited growth in batch cultures. In these cultures an $\mathrm{Mg}^{2+}$ shift-up from $5 \mu \mathrm{M}$ to $1 \mathrm{mM}$ resulted in a synchronized cell division without alterations in the rate of general macromolecule synthesis. Similar $\mathbf{M g}^{2+}$ shift-up experiments in continuous cultures have indicated that low $\mathrm{Mg}^{2+}$ inhibits the synthesis of a protein that might be involved in cell division (Utkilen \& Gulliksen, 1983). However, increasing/decreasing the $\mathrm{Mg}^{2+}$ concentration by changing the medium reservoir was not thought to be an ideal system for further studies of the $\mathrm{Mg}^{2+}$-controlled events in cell division. We were therefore interested in developing a system where the availability of $\mathrm{Mg}^{2+}$ could be altered in a more appropriate fashion. Since $A$. nidulans is a phototrophic organism, it should be possible to alter the availability of $\mathbf{M g}^{2+}$, even at low $\mathrm{Mg}^{2+}$ concentrations, by shifting between high and low light intensities.

This paper describes the effect of photon fluence rate on cell size and macromolecular composition of $A$. nidulans grown in $\mathrm{Mg}^{2+}$-limited and $\mathrm{Mg}^{2+}$-sufficient continuous cultures.

$\dagger$ Present address: Water and Health Department, National Institute of Public Health, Postuttak, Oslo 1, Norway.

$\ddagger$ Present address: Department of Microbiology, Agricultural University of Norway, PO Box 40, N-1432 AasNLH, Norway. 


\section{METHODS}

Organism and cultivation conditions. Anacystis nidulans (Strain UTEX 625 of the Culture Collection of Algae, Department of Botany, University of Texas), was grown in continuous culture as described previously (Utkilen, 1982). The cultures were fed with a modified medium $\mathrm{C}$ (Utkilen, 1982), where the $\mathrm{Mg}^{2+}$ concentration was lowered to 5 or $10 \mu \mathrm{M}$ or the $\mathrm{Ca}^{2+}$ concentration was lowered to about $0 \cdot 2 \mu \mathrm{M}\left(0 \cdot 1 \mu \mathrm{M}-\mathrm{CaCl}_{2}\right.$ was added, the remainder was due to impurities from other chemicals). In the latter culture the $\mathrm{Mg}^{2+}$ concentration was increased to $1 \mathrm{~mm}$.

The growth temperature was $40^{\circ} \mathrm{C}$ and the dilution rate $0.09 \mathrm{~h}^{-1}$. The culture vessel was placed between two ranks of fluorescent tubes (Utkilen, 1982), which gave an incident photon fluence rate of $445 \mu \mathrm{E} \mathrm{m}^{-2} \mathrm{~s}^{-1}$ at both sides of the culture vessel. The photon fluence rate was measured by LI Quantum/Radiometer/Photometer (Lambda Instruments, Chicago, USA) and was decreased by placing white paper sheets between the fluorescent tubes and the waterbath.

Analytical Procedures. Cell number and volume were determined by means of an electronic particle counter (Coulter counter model ZB industrial, Coulter Electronics, Dunstable, UK) as described earlier (Utkilen, 1982). For dry weight estimations, $50 \mathrm{ml}$ of culture was harvested by centrifugation $(15000 \mathrm{~g}, 10 \mathrm{~min})$, washed with distilled water, and transferred to small dried and preweighed glass tubes. These were dried overnight at $95^{\circ} \mathrm{C}$, and placed in a desiccator for $8 \mathrm{~h}$ before reweighing. Samples for protein, RNA and DNA determinations were harvested as above, washed once with distilled water and stored at $-20^{\circ} \mathrm{C}$ until the experiment was completed. Before assay of the individual components, chlorophyll was extracted with $5 \mathrm{ml}$ methanol. For protein estimation, the pellet was resuspended in $0.5 \mathrm{ml}$ distilled water, and protein was assayed by the Lowry method. For RNA estimation, the pellet was resuspended in $0.2 \mathrm{M}-\mathrm{NaCl}(2.5 \mathrm{ml})$, then $0.1 \mathrm{ml}$ perchloric acid $(60 \%$, w/v $)$ was added and after incubation at $70{ }^{\circ} \mathrm{C}$ for $80 \mathrm{~min}$ the suspension was chilled on ice and centrifuged; $1 \mathrm{ml}$ of the supernatant was assayed for D-ribose by the orcinol method of Herbert et al. (1971), using RNA from yeast as standard. DNA was measured by the method of Burton (1956), with rat testicular DNA as standard.

For chlorophyll estimations, $50 \mathrm{ml}$ samples were washed once with distilled water and resuspended in $5 \mathrm{ml}$ acetone. The suspension was sonicated using a Sonorode $100 \mathrm{~W}$ ultrasonic drill (Kerry's Ultrasonics, London, UK) for three periods of $1 \mathrm{~min}$, while cooling in ice. The suspension was then placed in the dark at room temperature for I h. After centrifugation, the $A_{665}$ of the supernatant was measured (Pye Unicam SP1800 spectrophotometer) and the chlorophyll $a$ concentration was calculated by the method of Parsons \& Strickland (1963).

\section{RESULTS AND DISCUSSION}

The steady state biomass in a culture fed with $5 \mu \mathrm{M}-\mathrm{Mg}^{2+}$ was independent of photon fluence rate between 445 and $233 \mu \mathrm{E} \mathrm{m}^{-2} \mathrm{~s}^{-1}$, while the biomass decreased with photon fluence rate below $233 \mu \mathrm{E} \mathrm{m}^{-2} \mathrm{~s}^{-1}$ (Fig. 1a). For the culture fed with $10 \mu \mathrm{M}-\mathrm{Mg}^{2+}$, the biomass decreased with photon fluence rate from $445 \mu \mathrm{E} \mathrm{m}^{-2} \mathrm{~s}^{-1}$ (Fig. 1 b). Increasing the $\mathrm{Mg}^{2+}$ concentration in the medium reservoir from 5 to $10 \mu \mathrm{M}$ at $108 \mu \mathrm{E} \mathrm{m}^{-2} \mathrm{~s}^{-1}$ did not result in any changes of the steady state in this culture.

The steady state cell mass should increase linearly with the input concentration of limiting nutrient and extrapolate to zero if this nutrient is the only limiting factor (Herbert et al., 1956). However, the relationship between biomass and photon fluence rate can not be extrapolated, since it is non-linear at low photon fluence rates (Van Liere, 1979). There was a linear relation between steady state biomass and photon fluence rate from 108 to $32 \mu \mathrm{E} \mathrm{m}^{-2} \mathrm{~s}^{-1}$ in the culture fed with $5 \mu \mathrm{M}-\mathrm{Mg}^{2+}$ (Fig. 1 a). This indicated that the culture was limited by the photon fluence rate below $108 \mu \mathrm{E} \mathrm{m}^{-2} \mathrm{~s}^{-1}$. The fact that increasing the $\mathrm{Mg}^{2+}$ concentration in supplied medium from 5 to $10 \mu \mathrm{M}-\mathrm{Mg}^{2+}$ at $108 \mu \mathrm{E} \mathrm{m}^{-2} \mathrm{~s}^{-1}$ had no effect on the steady state also supported this. It therefore seems reasonable to conclude that the culture fed with $5 \mu \mathrm{M}-\mathrm{Mg}^{2+}$ was $\mathrm{Mg}^{2+}$-limited above $233 \mu \mathrm{E} \mathrm{m}^{-2} \mathrm{~s}^{-1}$ (Utkilen, 1982) and that a transition to photon fluence rate limitation was obtained between 233 and $108 \mu \mathrm{E} \mathrm{m}^{-2} \mathrm{~s}^{-1}$, whereas the culture was limited by the photon fluence rate below $108 \mu \mathrm{E} \mathrm{m}^{-2} \mathrm{~s}^{-1}$. Since the steady state dry weight at the low photon fluence rates was the same for the cultures fed with $10 \mu \mathrm{M}-\mathrm{Mg}^{2+}$ and $0 \cdot 2 \mu \mathrm{M}-\mathrm{Ca}^{2+}$ (not shown) as for the culture fed with $5 \mu \mathrm{M}-\mathrm{Mg}^{2+}$, all the cultures used probably were limited by the photon fluence rate below $100 \mu \mathrm{E} \mathrm{m}^{-2} \mathrm{~s}^{-1}$. Therefore the effect of a transition from nutrient limited to photon fluence rate limited conditions was studied in the cultures used.

At the high photon fluence rates the mean cell volume in the culture fed with $5 \mu \mathrm{M}-\mathrm{Mg}^{2+}$ was twice that in the cultures fed with $10 \mu \mathrm{M}-\mathrm{Mg}^{2+}$ (Fig. 1), or $0 \cdot 2 \mu \mathrm{M}-\mathrm{Ca}^{2+}$ (Table 1). The 'normal' 


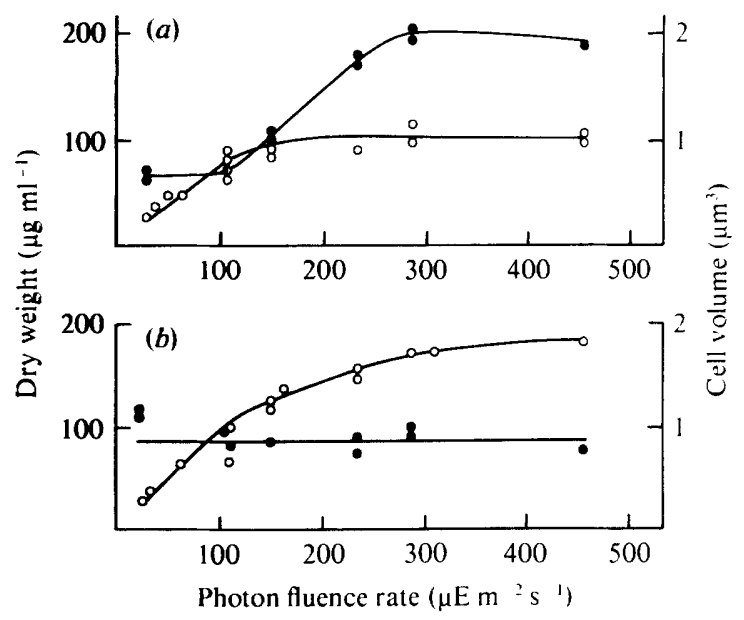

Fig. 1. Steady state dry weight $(O)$ and cell size $(\bigcirc)$ as functions of photon fluence rate for $A$. nidulans grown in a continuous culture fed with $5 \mu \mathrm{M}-\mathrm{Mg}^{2+}(a)$ and $10 \mu \mathrm{M}-\mathrm{Mg}^{2+}(b)$, at $D=0.09 \mathrm{~h}^{-1}$.

Table 1. Variations in A. nidulans cell size and some cellular parameters with photon fluence rate

A continuous culture was fed with $0.2 \mu \mathrm{M} \mathrm{Ca}^{2+}$, at $D=0.09 \mathrm{~h}^{-1}$. All values are means obtained from two samples harvested and processed on different days, at each steady state.

\begin{tabular}{|c|c|c|c|c|}
\hline $\begin{array}{l}\text { Photon fluence } \\
\left(\mu \mathrm{E} \mathrm{m}^{-2} \mathrm{~s}^{-1}\right)\end{array}$ & $\begin{array}{l}\text { Cell size } \\
\left(\mu \mathrm{m}^{3}\right)\end{array}$ & $\begin{array}{c}\text { Protein } \\
\left(\mathrm{pg} \text { cell }^{-1}\right)\end{array}$ & $\begin{array}{c}\text { RNA } \\
\left(\mathrm{pg} \text { cell }^{-1}\right)\end{array}$ & RNA/Protein \\
\hline 610 & 0.8 & $0 \cdot 25$ & 0.06 & $0 \cdot 24$ \\
\hline 435 & 0.9 & $0 \cdot 23$ & $0 \cdot 05$ & $0 \cdot 22$ \\
\hline 88 & 1.0 & 0.27 & 0.03 & $0 \cdot 11$ \\
\hline 31 & $1 \cdot 0$ & $0 \cdot 35$ & 0.03 & 0.09 \\
\hline
\end{tabular}

cell size, that is the mean cell volume obtained when the organism was grown with surplus $\mathrm{Mg}^{2+}$, was between 0.7 and $0.9 \mu \mathrm{m}^{3}$ at $D=0.09 \mathrm{~h}^{-1}$ (Utkilen, 1982). This was the mean cell volume obtained at all photon fluence rates in the culture fed with $10 \mu \mathrm{M}-\mathrm{Mg}^{2+}($ Fig. $1 b)$ or $0 \cdot 2 \mu \mathrm{M}-\mathrm{Ca}^{2+}$ (Table 1). The mean cell volume for the culture fed with $5 \mu \mathrm{M}-\mathrm{Mg}^{2+}$ attained this value at about $100 \mu \mathrm{E} \mathrm{m}^{-2} \mathrm{~s}^{-1}$ (Fig. 1 a). Since cell size has been shown to be more sensitive to insufficient $\mathrm{Mg}^{2+}$ than macromolecule synthesis (Utkilen, 1982), these results also indicated that the availability of $\mathrm{Mg}^{2+}$ was not limited below $100 \mu \mathrm{E} \mathrm{m}^{-2} \mathrm{~s}^{-1}$.

The decrease in cell volume between 282 and $150 \mu \mathrm{E} \mathrm{m}^{-2} \mathrm{~s}^{-1}$ was not principally caused by an increase in available $\mathrm{Mg}^{2+}$ per unit biomass, since steady state dry weight was unaltered at these photon fluence rates. In this case the increase in available cellular $\mathbf{M g}^{2+}$ for cell division could arise from a decrease in cellular compounds binding $\mathrm{Mg}^{2+}$. The decrease in RNA (Fig. 2a), which occurs before the decrease in dry weight (Fig. $1 a$ ) is a good example, since RNA is one of the main $\mathrm{Mg}^{2+}$-binding components (Jasper \& Silver, 1977). Thus, under certain conditions cell size might also be a good indicator of alterations in availability of $\mathrm{Mg}^{2+}$ within the cell.

Decreasing the photon fluence rate resulted in an increase of chlorophyll $a$ content from 1 to $2 \%$ of dry weight for the cultures fed with 5 or $10 \mu \mathrm{M}-\mathrm{Mg}^{2+}$ (not shown). The maximal chlorophyll content was reached at about $230 \mu \mathrm{E} \mathrm{m}^{-2} \mathrm{~s}^{-1}$ in the culture fed with $10 \mu \mathrm{M}-\mathrm{Mg}^{2+}$, and at about $150 \mu \mathrm{E} \mathrm{m}^{-2} \mathrm{~s}^{-1}$ in the culture fed with $5 \mu \mathrm{M}-\mathrm{Mg}^{2+}$. In the culture fed with $0 \cdot 2 \mu \mathrm{M}-\mathrm{Ca}^{2+}$ chlorophyll $a$ increased from 0.5 to $1.7 \%$ of dry weight as the photon fluence rate decreased from 600 to $30 \mu \mathrm{E} \mathrm{m}^{-2} \mathrm{~s}^{-1}$. These results showed that the $\mathrm{Mg}^{2+}$-limited conditions used had no inhibitory effect on chlorophyll synthesis and that the maximal chlorophyll content in $A$. nidulans seemed to be about $2 \%$ of dry weight. 



Fig. 2. Influence of photon fluence rate on $A$. nidulans cell protein $(O, \odot)$ and $\operatorname{RNA}(\triangle, \Delta)$, for a continuous culture fed with $5 \mu \mathrm{M}-\mathrm{Mg}^{2+}(\mathrm{O}, \triangle)$ and $10 \mu \mathrm{M}-\mathrm{Mg}^{2+}(\mathbf{O}, \Delta)$ at $D=0.09 \mathrm{~h}^{-1}(a)$, and on the RNA/protein ratio for a culture fed with $5 \mu \mathrm{M}-\mathrm{Mg}^{2+}(O)$ and $10 \mu \mathrm{M}-\mathrm{Mg}^{2+}(O)$ at $D=0.09 \mathrm{~h}^{-1}(b)$.

\section{Table 2. Cell number and amount of DNA per cell as function of photon fluence rate}

Continuous cultures of $A$. nidulans were fed with 5 or $10 \mu \mathrm{M}-\mathrm{Mg}^{2+}$ at $D=0.09 \mathrm{~h}^{-1}$. All values are means obtained from two samples harvested and processed on different days, at each steady state.

\begin{tabular}{|c|c|c|c|c|}
\hline \multirow{2}{*}{$\begin{array}{l}\text { Photon fluence rate } \\
\qquad\left(\mu E \mathrm{~m}^{-2} \mathrm{~s}^{-1}\right)\end{array}$} & \multicolumn{2}{|c|}{$\begin{array}{l}10^{-6} \times \mathrm{No} \\
\text { of cells } \mathrm{ml}^{-1}\end{array}$} & \multicolumn{2}{|c|}{$\begin{array}{l}\text { DNA per cell } \\
(\mathrm{pg})\end{array}$} \\
\hline & $5 \mu \mathrm{M}-\mathrm{Mg}^{2+}$ & $10 \mu \mathrm{M}-\mathrm{Mg}^{2+}$ & $5 \mu \mathrm{M}-\mathrm{Mg}^{2+}$ & $10 \mu \mathrm{M}-\mathrm{Mg}^{2+}$ \\
\hline 445 & 6.7 & $22 \cdot 0$ & 0.022 & 0.012 \\
\hline 282 & $4 \cdot 5$ & $15 \cdot 9$ & 0.029 & 0.014 \\
\hline 233 & $6 \cdot 6$ & 19.0 & 0.017 & 0.011 \\
\hline 149 & 9.0 & 13.6 & 0.020 & 0.012 \\
\hline 103 & $8 \cdot 8$ & $10 \cdot 4$ & 0.013 & 0.011 \\
\hline 31 & $2 \cdot 7$ & $2 \cdot 3$ & 0.015 & 0.017 \\
\hline
\end{tabular}

At high photon fluence rates the cellular DNA content at $5 \mu \mathrm{M}-\mathrm{Mg}^{2}$ was twice that for the cells grown with $10 \mu \mathrm{M}-\mathrm{Mg}^{2+}$ (Table 2). However, cell size at $5 \mu \mathrm{M}-\mathrm{Mg}^{2+}$ was also about twice that at $10 \mu \mathrm{M}-\mathrm{Mg}^{2+}$ (Fig. 1), and DNA per unit cell volume was therefore the same at both $\mathrm{Mg}^{2+}$ concentrations. Thus $5 \mu \mathrm{M}-\mathrm{Mg}^{2+}$ does not influence cell division by interfering with DNA synthesis. The DNA content was the only parameter investigated which was independent of photon fluence rate. This was what one would expect since growth rate and DNA replication are closely connected in both bacteria (Cooper \& Helmstetter, 1968) and cyanobacteria (Mann \& Carr, 1974 ) and the growth rate in the present experiments was held constant. The RNA content decreased with photon fluence rate below $300 \mu \mathrm{E} \mathrm{m}^{-2} \mathrm{~s}^{-1}$ (Fig. $2 a$ ) and this resulted in an increase of the DNA/RNA ratio with decreasing photon fluence rate. The DNA/RNA ratio has been shown to be independent of growth rate in A. nidulans (Mann \& Carr, 1974; Briseid, 1981). This led Mann \& Carr (1974) to suggest that cyanobacteria were unable to respond to an altered growth rate by altering the relative frequency of transcription of the stable RNA genes. However, the observed increase in DNA/RNA with decreasing photon fluence rate shows that the transcription of the RNA genes can be altered and that variations in RNA synthesis are coupled to energy metabolism. Variation in RNA content with photon fluence rate may explain why 
Mann \& Carr (1974) observed a faster increase in RNA than cell mass or cell volume when they increased the growth rate of $A$. nidulans by increasing the photon fluence rate in batch cultures.

RNA and protein levels also showed different patterns with decreasing photon fluence rate (Fig. 2a). This resulted in a decrease of the RNA/protein ratio from about 0.3 at $445 \mu \mathrm{E} \mathrm{m}^{-2} \mathrm{~s}^{-1}$ to 0.1 at $108 \mu \mathrm{E} \mathrm{m}^{-2} \mathrm{~s}^{-1}$ (Fig. $2 b$ ), showing that the organism contained three times more RNA at high photon fluence rates than the minimum needed to cope with the imposed dilution rate. It has been shown that the efficiency of cellular RNA in $A$. nidulans varies with growth rate (Briseid, 1981; Utkilen, 1982). The results presented here (Fig. $2 b$ ) show that the efficiency also might vary at constant growth rate and that energy was the main regulator under these circumstances.

Decreasing the photon fluence rate from about 445 to $30 \mu \mathrm{E} \mathrm{m}^{-2} \mathrm{~s}^{-1}$ for $\mathrm{Mg}^{2+}-$ limited and non- $\mathrm{Mg}^{2+}$-limited cultures revealed that the macromolecules in these cultures followed the same pattern under these conditions (Figs 1 and 2; Tables 1 and 2). This demonstrated that the $\mathrm{Mg}^{2+}$ limited conditions used did not result in any severe changes in macromolecule synthesis. The response of mean cell volume to photon fluence rate (Fig. 1) was the only difference found between the $\mathrm{Mg}^{2+}$-limited and non- $\mathrm{Mg}^{2+}$-limited conditions. This is in accordance with the results obtained during $\mathrm{Mg}^{2+}$ shift-up from 5 to $100 \mu \mathrm{M}-\mathrm{Mg}^{2+}$ in batch cultures (Utkilen, 1982). Altering the photon fluence rate for a continuous culture of $A$. nidulans fed with $5 \mu \mathrm{M}-\mathrm{Mg}^{2+}$ should therefore provide a useful approach for further studies of the $\mathrm{Mg}^{2+}$-controlled events in cell division.

\section{REFERENCES}

Ahluwalia, B., Duffus, J. H., Paterson, L. J. \& WALKER, G. M. (1978). Synchronization of cell division in the fission yeast Schizosaccharomyces pombe by ethylenediaminetetra-acetic acid. Journal of General Microbiology 106, 261-264.

BRISEID, T. K. (1981). Vekst av Anacystis nidulans (Synechococcus) $i K^{+}$-begrenset kjemostat. Thesis, University of Oslo, Norway.

BURTON, K. (1956). A study of the conditions and mechanisms of the colorimetric estimation of deoxyribonucleic acid. Biochemical Journal 62, 315-322.

ClaRK, D. J. (1968). Regulation of deoxyribunucleic acid replication and cell division in Escherichia coli B/r. Journal of Bacteriology 96, 1214-1224.

Cooper, S. \& Helmstetter, C. E. (1968). Chromosome replication and the cell division cycle of Escherichia coli B/r. Journal of Molecular Biology 31, 519-540.

Finkel, B. J. \& Appleman, D. (1953). The effect of magnesium concentration on the growth of Chlorella. Plant Physiology 28, 664-673.

Herbert, D., Elsworth, R. \& Telling, R. C. (1956). The continuous culture of bacteria; a theoretical and experimental study. Journal of General Microbiology 14, 601-622.

Herbert, D., Phipps, P. J. \& Strange, R. E. (1971). Chemical analysis of microbial cells. Methods in Microbiology 5B, 209-344.

JASPER, P. \& SILVER, S. (1977). Magnesium transport in microorganisms. In Microorganisms and Minerals, pp. 7-47. Edited by E. P. Weinberg. New York: Marcel Dekker.

Lutkenhaus, J. F. \& Donachie, W. D. (1979).
Identification of the ftsA gene product. Journal of Bacteriology 137, 1088-1094.

MANN, N. \& CARR, N. G. (1974). The control of macromolecular composition and cell division in the bluegreen alga Anacystis nidulans. Journal of General Microbiology 83, 399-405.

Parsons, T. R. \& Strickland, J. D. H. (1963). Discussion of spectrophotometric determination of marine plant-pigments, with a revised equation for ascertaining chlorophylls and carotenoids. Journal of Marine Research 21, 153-163.

Pierucci, O. \& Helmstetter, C. E. (1969). Chromosome replication, protein synthesis and cell division in Escherichia coli. Federation Proceedings 28, 17551760.

UTKILEN, H. C. (1982). Magnesium-limited growth of the cyanobacterium Anacystis nidulans. Journal of General Microbiology 128, 1849-1862.

UtKilen, H. C. \& Gulliksen, O. M. (1983). A preliminary identification of a possible cell division protein in Anacystis nidulans. Journal of General Microbiology 129, 2285-2291.

VAN LIERE, L. (1979). On Oscillatoria agardhii Gomont, experimental ecology and physiology of a nuisance bloom-forming cyanobacterium. PhD thesis. University of Amsterdam, The Netherlands.

WEBB, M. (1949). The influence of magnesium on cell division. 2. The effect of magnesium on the growth and cell division of various bacterial species in complex media. Journal of General Microbiology 3, $410-417$.

WEBB, M. (1953). Effects of magnesium on cell division in bacteria. Science 118, 607-611. 